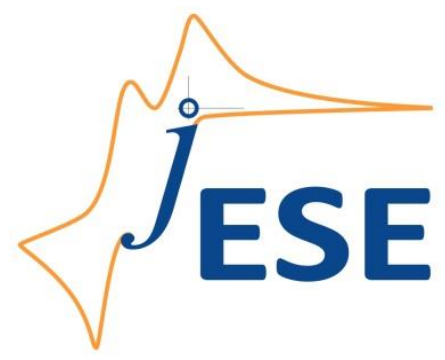

Open Access: ISSN 1847-9286

www.jESE-online.org

Original scientific paper

\title{
Electrodeposition of $\mathrm{Sb}_{2} \mathrm{Se}_{3}$ thin films on various substrates from the tartaric electrolyte
}

Vusala Asim Majidzade ${ }^{1, \bigotimes}$, Akif Shikhan Aliyev ${ }^{1}$, Parvin Heydar Guliyev², Dunya Mahammad Babanly ${ }^{1,3}$

${ }^{1}$ Institute of Catalysis and Inorganic Chemistry named after acad. M. Nagıyev Azerbaijan National Academy of Sciences (ANAS), Baku, AZ1143, Azerbaijan

${ }^{2}$ Nakchivan State University, Nakchivan AR, AZ 7012, Azerbaijan

${ }^{3}$ French Azerbaijani University (UFAZ), Baku, AZ1010, Azerbaijan

Corresponding author: ${ }^{\circledR}$ vuska 80@mail.ru, Phone: +99450 6400225

Received: March 4, 2019; Revised: July 1, 2019; Accepted: July 2, 2019

\begin{abstract}
The present contribution is devoted to the electrochemical deposition of $\mathrm{Sb}_{2} \mathrm{Se}_{3}$ thin films from tartrate electrolyte. The study was conducted by potentiodynamic, potentiostatic and galvanostatic methods carried out under different conditions at Pt, Cu and Ni electrodes. The kinetics and mechanism of the electroreduction of antimony and selenite ions in the tartaric acid were studied separately for the electrochemical deposition. Comparison of the obtained polarization curves showed that co-deposition occurs between electroreduction potentials of antimony and selenium, indicating depolarization electrode effect for antimony ions. The influence of electrolyte composition, $\mathrm{pH}$, current density, temperature, etc. has been studied. On the basis of cyclic polarization, X-ray phase and SEM-EDX analyses, it is found that Sb-Se thin films are deposited on Pt and Ni electrodes, but not on $\mathrm{Cu}$ electrode. Black, uniform, crystalline and shiny films of the stoichiometric composition of $\mathrm{Sb}_{2} \mathrm{Se}_{3}$ compound are deposited on Pt and Ni electrodes within the 338-348 $\mathrm{K}$ temperature interval, $\mathrm{pH} 1.85$, current density of 2.5-3.0 A/dm $\mathrm{dm}^{2}$, and annealing temperature of $703 \mathrm{~K}$. Experiments were carried out using the optimal electrolyte composition containing $0.05 \mathrm{M}$ $\mathrm{SbOCl}+0.05 \mathrm{M} \mathrm{H}_{2} \mathrm{SeO}_{3}+0.007 \mathrm{M} \mathrm{C}_{4} \mathrm{H}_{6} \mathrm{O}_{6}$.
\end{abstract}

Keywords

Antimony triselenide; semiconductor; electrochemical deposition; polarization; tartaric acid

\section{Introduction}

Metal chalcogenides represent an important class of functional semiconductor materials possessing highly usable properties [1-3]. These materials are widely used as catalysts for photovoltaic cells, photoresistors, and laser materials because of their photosensitive and 
thermoelectric properties [4-10]. The economic drive to make efficient, low-cost solar cells requires sustained research on new absorber materials for thin-film photovoltaics [11-13].

Antimony selenide $\left(\mathrm{Sb}_{2} \mathrm{Se}_{3}\right)$ is considered one of the most promising semiconductor materials of the type $A_{2} B_{3}$ with a relevant bandgap of $\sim 1.78 \mathrm{eV}$ for solar cell applications [14]. This gives a solid argument for the production of this type of semiconductor materials which complements the field of application in electrochemistry. Relatively lower prices of Sb and $\mathrm{Se}$, as well as a low toxicity of $\mathrm{Sb}_{2} \mathrm{Se}_{3}$ merit its exploration for photovoltaic application.

There are different methods for obtaining thin films of metal-chalcogenides, including chemical vapor deposition, pyrolytic decomposition, thermal evaporation, hydrothermal synthesis, inert gas condensation and electrochemical method [15-25]. A highly crystalline $\mathrm{Sb}_{2} \mathrm{Se}_{3}$ sample was obtained by thermal evaporation and chemical precipitation method in a nitrogen atmosphere $[9,26]$. In a different work, $\mathrm{Sb}_{2} \mathrm{Se}_{3}$ was prepared by adding ethylene glycol to antimony oxide, and sodium selenosulfate. After 10-12 $\mathrm{h}$ at $423 \mathrm{~K}$ temperature, nanorods of $\mathrm{Sb}_{2} \mathrm{Se}_{3}$ with 10-15 mm length and 200-450 $\mathrm{nm}$ width were obtained [27].

All above-mentioned methods, however, are time, finance and effort consuming. The electrochemical method is more accurate, time-saving, and efficient method for the synthesis of metal chalcogenides including $\mathrm{Sb}_{2} \mathrm{Se}_{3}[7,8,28,29]$. Usually, this method is used to get thin layers of the required composition from electrolytes of different compositions in a short time and at relatively low temperatures. One of the advantages of this method is the possibility to alter the composition of the obtained layers by changing the composition of electrolyte and conditions of the electrolysis. The nucleation and the growth mechanisms of antimony selenide $\left(\mathrm{Sb}_{2} \mathrm{Se}_{3}\right)$ on indium-doped tin oxides (ITO) and fluorine tin oxide (FTO) substrates were achieved using the electrochemical method [7,30].

To obtain high-quality $\mathrm{Sb}_{2} \mathrm{Se}_{3}$ thin films with an electrochemical method, more accurate experimental results in this field of research are still required. This work is a part of our systematic investigation in the area of electrodeposition of thin films of semiconductor chalcogenides [31-37]. Therefore, the present contribution is devoted to exploring the optimal conditions for obtaining high-quality films of antimony selenide via studying the effect of the substrate material on the electrodeposition process.

\section{Experimental part}

The composition of an electrolyte solution used in our experiments was $0.01-0.09 \mathrm{M} \mathrm{SbOCl}$ (supplied by 2A Pharmachem, USA), $0.01-0.09 \mathrm{M} \mathrm{H}_{2} \mathrm{SeO}_{3}$ (supplied by Reachim LTD, Russia) and 0.007 $\mathrm{M} \mathrm{C}_{4} \mathrm{H}_{6} \mathrm{O}_{6}$ (tartaric acid) (supplied by IndiaMART, India). The cyclic polarization curves were performed via "IVIUMSTAT Electrochemical Interface" potentiostat. During experiments, a three-electrode electrochemical cell with $100 \mathrm{ml}$ volume, Pt wire of $2 \times 10^{-6} \mathrm{~m}^{2}$ surface and $\mathrm{Cu}$ and Ni plates of $1 \times 10^{-4}$ $\mathrm{m}^{2}$ surface area were used as working electrodes. The silver-silver chloride $(\mathrm{Ag} / \mathrm{AgCl} / \mathrm{KCl})$ was used as a reference electrode and a Pt sheet as a counter electrode. The temperature was regulated by the UTU - 4 universal thermostat. The phase composition of the prepared thin films was analyzed by "D2 Phazer" X-ray phase analyzer (CuK ; Ni filter) of the "Bruker" company. Morphology, topography and chemical elemental composition of the deposited samples were measured by "Carel Zeiss Sigma" scanning electron microscope (SEM) provided with EDX unit.

At the beginning of the experiments, $\mathrm{Pt}, \mathrm{Ni}$, and $\mathrm{Cu}$ electrodes were purified in the concentrated nitric acid and then washed with bi-distilled water. Ni-electrodes were additionally subjected to electrochemical polishing in a mixed solution of sulfuric, phosphoric and citric acids at certain conditions $\left(T=293-303 \mathrm{~K}, j=0.5 \mathrm{~A} / \mathrm{dm}^{2}, \tau=180 \mathrm{~s}\right)$ and washed with distilled water. 


\section{Results and discussion}

As is already known, the composition and quality of the obtained thin layers considerably depend on the composition of electrolyte and concentration of primary components during electrodeposition. In the present study, Sb-Se thin films were electrochemically deposited from tartrate electrolyte by galvanostatic and potentiostatic methods. We carried out the deposition process by changing certain conditions, such as current density, concentration of components, temperature, etc. Different substrate electrodes, i.e. Pt, $\mathrm{Cu}$, and $\mathrm{Ni}$ have been used to obtain the stoichiometric compound $\mathrm{Sb}_{2} \mathrm{Se}_{3}$. As a result, the composition of the electrolyte and the condition of electrolysis were optimized to the necessary extent.

Initially, Pt electrode was used to study the kinetics and mechanism of the electrochemical codeposition process. Experiments were carried within $0.01-0.1 \mathrm{M}$ concentration range of $\mathrm{SbOCl}$ and $\mathrm{H}_{2} \mathrm{SeO}_{3}$ acid in the presence of the tartaric acid, wherein the $\mathrm{pH}$ value varied in the interval of 1.65-2.1. The potentiodynamic method was used to record the cyclic polarization curves on the $\mathrm{Pt}$ electrode. After that, thin $\mathrm{Sb}-\mathrm{Se}$ films were deposited on $\mathrm{Ni}$ and $\mathrm{Cu}$ electrodes under optimal experimental conditions.

As can be seen from Figure 1, in comparison with other processes, the electroreduction of selenite ions occurs in stages. According to the reference [38], the standard electrode potential of selenite ions is more positive than antimony ions.
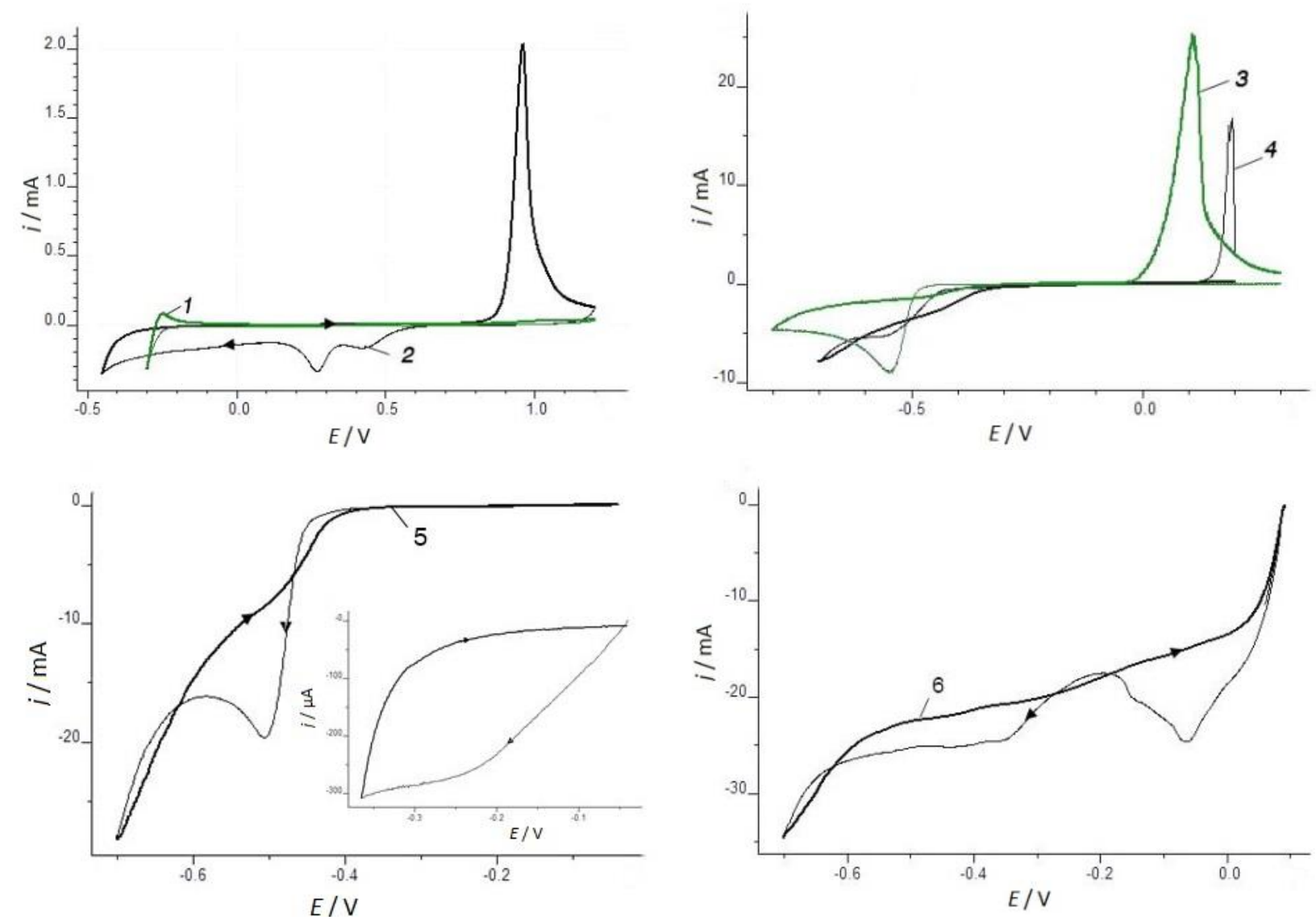

Figure 1. Cyclic polarization curves (I vs. E) of electroreduction of selenite and antimony ions in tartaric acid and co-deposition of Sb and Se on different electrodes. Composition of the electrolyte (M):

1) $0.007 \mathrm{C}_{4} \mathrm{H}_{6} \mathrm{O}_{6}$, on Pt electrode; 2) $0.05 \mathrm{H}_{2} \mathrm{SeO}_{3}+0.007 \mathrm{C}_{4} \mathrm{H}_{6} \mathrm{O}_{6}$ on Pt electrode;

3) $0.05 \mathrm{SbOCl}+0.007 \mathrm{C}_{4} \mathrm{H}_{6} \mathrm{O}_{6}$, on Pt electrode; 4) $0.05 \mathrm{SbOCl}+0.05 \mathrm{H}_{2} \mathrm{SeO}_{3}+0.007 \mathrm{C}_{4} \mathrm{H}_{6} \mathrm{O}_{6}$, on

Pt electrode; 5) $0.05 \mathrm{SbOCl}+0.05 \mathrm{H}_{2} \mathrm{SeO}_{3}+0.007 \mathrm{C}_{4} \mathrm{H}_{6} \mathrm{O}_{6}$, on Ni electrode;

6) $0.05 \mathrm{SbOCl}+0.05 \mathrm{H}_{2} \mathrm{SeO}_{3}+0.007 \mathrm{C}_{4} \mathrm{H}_{6} \mathrm{O}_{6}$ on Cu electrode. $\mathrm{T}=298 \mathrm{~K}, \mathrm{v}=0.02 \mathrm{~V} \mathrm{~s}^{-1}$. 
This affects co-electrodeposition and formation of the compound $\mathrm{Sb}_{2} \mathrm{Se}_{3}$ on $\mathrm{Pt}$ and Ni electrodes, which occurs between the potentials of the electroreduction of the antimony ions (-0.46 V) [32] and selenite ions $(0.4 \mathrm{~V})$ [33]. Co-deposition is indicated at $-0.44 \mathrm{~V}$, suggesting depolarization, i.e. decrease of the cathodic potential of electrode for antimony deposition. Starting from $-0.44 \mathrm{~V}$, the surfaces of Pt and Ni electrodes become completely covered with the black Sb-Se layer. As can be seen from the curve 6 in Figure 1, formation of Sb-Se compound on Cu electrode does not occur.

Further studies of the process of electrolysis on Ni-electrodes were carried out using both galvanostatic and potentiostatic methods. The films obtained by the galvanostatic method at current density of 2-6 $\mathrm{A} / \mathrm{dm}^{2}$ from an electrolyte of $0.05 \mathrm{MSbOCl}+0.05 \mathrm{M} \mathrm{H}_{2} \mathrm{SeO}_{3}+0.007 \mathrm{MC}_{4} \mathrm{H}_{6} \mathrm{O}_{6}$ were thermally treated at $T_{\text {thermal }}=673-773 \mathrm{~K}$ temperature range, in an argon atmosphere. The processes of electrodeposition and heat treatment lasted for $60 \mathrm{~min}$ each. The purpose of heat treatment was to obtain crystalline films of $\mathrm{Sb}_{2} \mathrm{Se}_{3}$. Before and after annealing, the obtained thin films were investigated using X-ray phase, SEM and elemental analyses. The results of SEM-EDX analysis presented in Figure 2 show that thin films obtained at a current density of 2-3 A/dm ${ }^{2}$ are close to the stoichiometric composition.
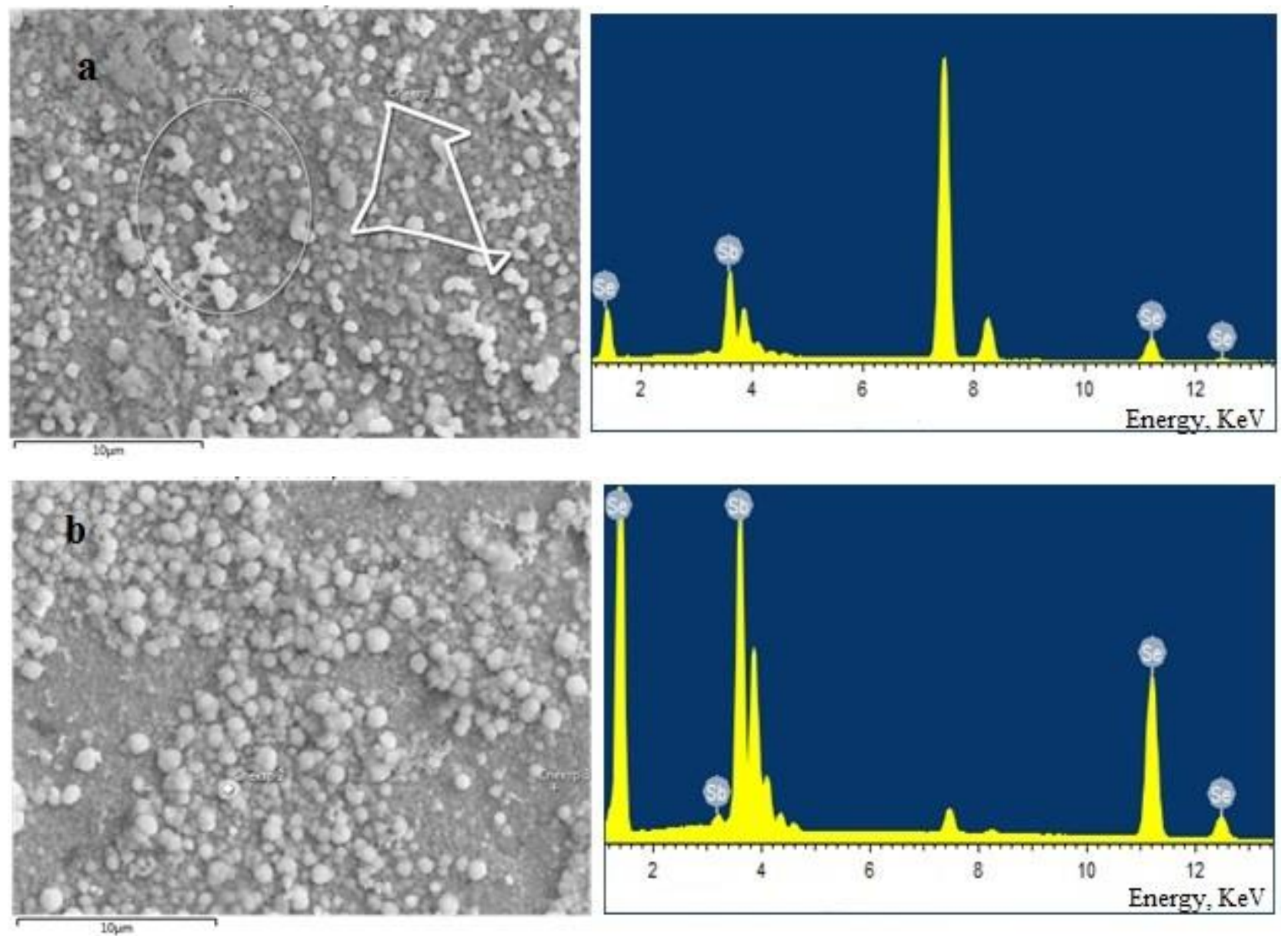

Figure 2. SEM-EDX results of Sb-Se layers electrodeposited on Ni-electrode: a) galvanostatic method, electrolyte composition $0.09 \mathrm{M} \mathrm{SbOCl}+0.01 \mathrm{M} \mathrm{H}_{2} \mathrm{SeO}_{3}+0.007 \mathrm{M} \mathrm{C}_{4} \mathrm{H}_{6} \mathrm{O}_{6}$,

current density $\left.=2.5 \mathrm{~A} / \mathrm{dm}^{2}, \mathrm{~T}=298 \mathrm{~K}, \mathrm{pH} 2.1, \mathrm{~T}_{\text {thermal }}=703 \mathrm{~K} ; \mathrm{b}\right)$ galvanostatic method, electrolyte composition $0.05 \mathrm{M} \mathrm{SbOCl}+0.05 \mathrm{M} \mathrm{H}_{2} \mathrm{SeO}_{3}+0.007 \mathrm{M} \mathrm{C}_{4} \mathrm{H}_{6} \mathrm{O}_{6}$, current density $=2.5 \mathrm{~A} / \mathrm{dm}^{2}$,

$\mathrm{T}=298 \mathrm{~K}, \mathrm{pH} 1.85$, not thermally treated; c) potentiostatic method, electrolyte composition $0.05 \mathrm{M} \mathrm{SbOCl}+0.05 \mathrm{M} \mathrm{H}_{2} \mathrm{SeO}_{3}+0.007 \mathrm{M} \mathrm{C}_{4} \mathrm{H}_{6} \mathrm{O}_{6}$, $\mathrm{E}=-0.55 \mathrm{~V}, \mathrm{~T}=338 \mathrm{~K}, \mathrm{pH}=1.85, \mathrm{~T}_{\text {thermal }}=703 \mathrm{~K}$. 
The content of antimony and selenium in the film is 61.91 at. \% and 38.09 at. \%, respectively. It was shown previously that the antimony content in the deposited film decreases with an increase of current density to $6 \mathrm{~A} / \mathrm{dm}^{2}$ [34]. The co-deposition of Sb-Se layers on $\mathrm{Ni}$ electrode by the potentiostatic method was carried out at 298-358 $\mathrm{K}$ temperature range. Obtained results show that the stoichiometric $\mathrm{Sb}_{2} \mathrm{Se}_{3}$ samples are formed starting from $338 \mathrm{~K}$. This is evidenced by the X-ray phase results of samples (Figure 3).

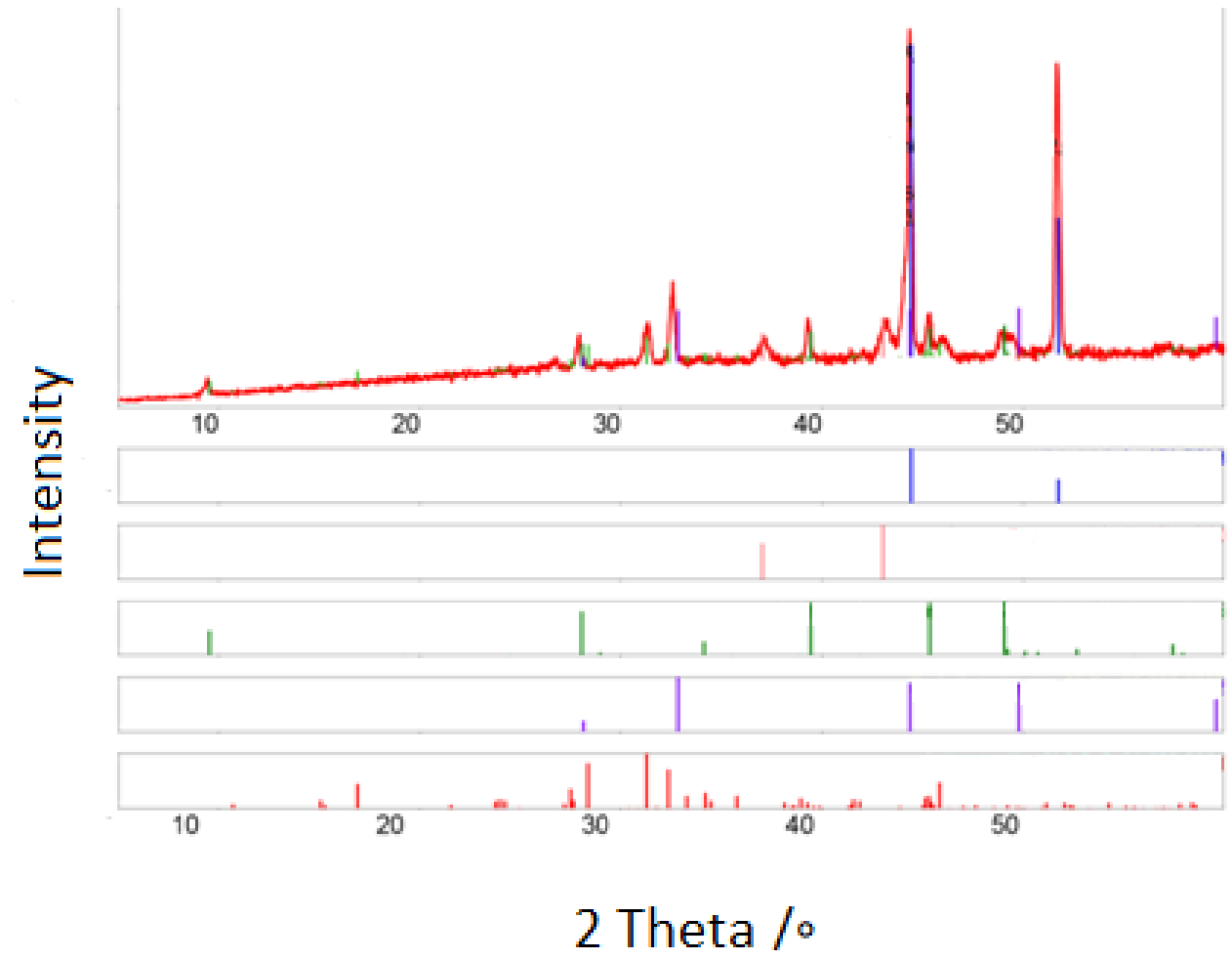

Figure 3. $X$-ray phase analysis of $\mathrm{Sb}$-Se films formed by potentiostatic deposition on Ni-electrode. The composition of electrolyte: $0.05 \mathrm{M} \mathrm{SbOCl}+0.05 \mathrm{M} \mathrm{H}_{2} \mathrm{SeO}_{3}+0.007 \mathrm{M} \mathrm{C}_{4} \mathrm{H}_{6} \mathrm{O}_{6}$, $\mathrm{E}=-0.55 \mathrm{~V}$, time of electrolysis $=60 \mathrm{~min}, \mathrm{~T}=338 \mathrm{~K}, \mathrm{pH}=1.85, \mathrm{~T}_{\text {thermal }}=703 \mathrm{~K}$.

It was established that co-deposition of Sb-Se thin films at $298 \mathrm{~K}$ occurs at $-0.6 \mathrm{~V}$, while at $358 \mathrm{~K}$, the potential of co-deposition is shifted to $-0.36 \mathrm{~V}$, suggesting that an increase in temperature has a positive effect on co-precipitation. During these experiments, the color of the samples varied from golden red to black. It was also observed that the composition of layers obtained within the temperature range $338-348 \mathrm{~K}$ is closer to the stoichiometric one (Figure 2c). Adhesion of films obtained at $T>348 \mathrm{~K}$, however, deteriorates and therefore falls from the surface of the electrode.

$\mathrm{Sb}$-Se thin films were also deposited on $\mathrm{Cu}$ electrode. This process was carried out under the galvanostatic regime at $2-2.5 \mathrm{~A} / \mathrm{dm}^{2}$ current density in different concentrations of the electrolyte. The obtained samples were further annealed at $723 \mathrm{~K}$ in an argon environment. As shown in Figures 4 and 5 , the results of X-ray phase analysis on Cu-electrode differ from the results obtained on Ni electrodes.

The duration of electrolysis and heat treatment on Cu-electrodes lasted for 60 min each. As can be seen from Figures 4 and 5 , the electrodeposition of antimony does not occur on the surface of $\mathrm{Cu}$ electrode. In all studied concentration intervals of the initial components, the chemical compound $\mathrm{Cu}_{2} \mathrm{Se}$ is formed. In our opinion, this is because selenium is deposited at more positive potential as compared to $\mathrm{Sb}$, and the electrode surface is completely covered with selenium. Therefore, the formation of $\mathrm{Cu}_{2} \mathrm{Se}$ compound occurs after heat treatment and the interaction of antimony with selenium does not occur. 

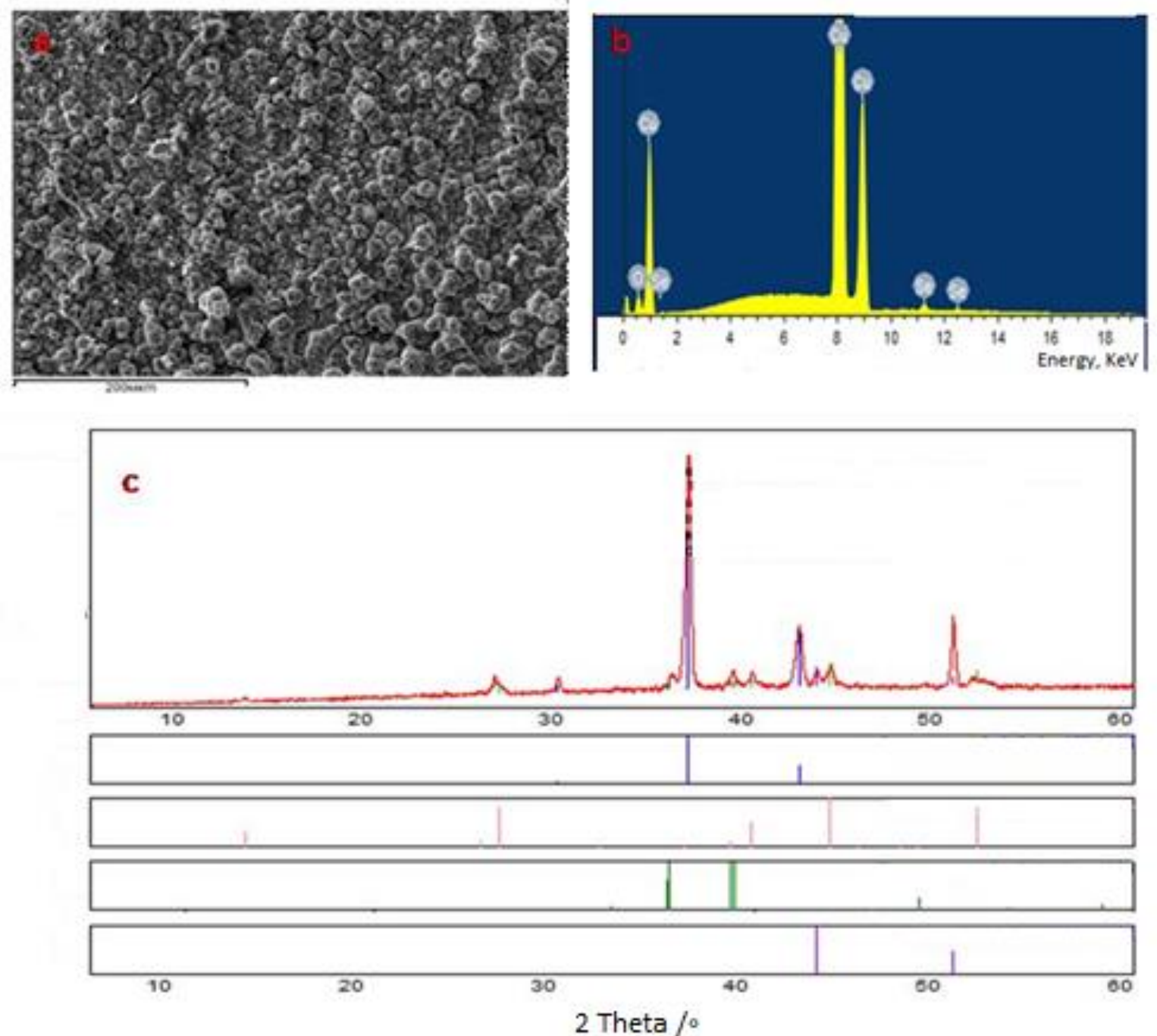

Figure 4. a) SEM, b) EDX and c) X-ray phase analysis of electrodeposited layers on Cu electrode.

Electrolyte composition: $0.025 \mathrm{M} \mathrm{SbOCl}+0.075 \mathrm{M} \mathrm{H}_{2} \mathrm{SeO}_{3}+0.007 \mathrm{M} \mathrm{C}_{4} \mathrm{H}_{6} \mathrm{O}_{6}$, time of electrolysis $=60 \mathrm{~min}$, current density $=2.5 \mathrm{~A} / \mathrm{dm}^{2}, \mathrm{~T}=298 \mathrm{~K}, \mathrm{pH} \mathrm{1.73,} \mathrm{T}_{\text {thermal }}=703 \mathrm{~K}$

The main results of present experiments are summarized in Table 1, showing that the chemical composition of Sb-Se films is closer to the stoichiometric one when they are deposited on the surface of $\mathrm{Pt}$ and Ni electrodes. The compound $\mathrm{Sb}_{2} \mathrm{Se}_{3}$ does not form on the Cu electrode. Thus, the obtained results have proved that the electrode support material has a considerable influence on the co-deposition process, and that Pt and Ni electrodes are more effective for co-deposition of SbSe thin films than Cu electrode.

Table 1. Chemical compositions of $\mathrm{Sb}_{2} \mathrm{Se}_{3}$ thin films formed by galvanostatic deposition* from tartaric electrolyte containing different concentrations of $\mathrm{Sb}$ and Se on different substrate electrodes.

\begin{tabular}{|c|c|c|c|c|c|c|c|c|c|}
\hline \multirow{4}{*}{ No. } & \multirow{3}{*}{\multicolumn{2}{|c|}{$\begin{array}{l}\text { Composition of } \\
\text { electrolyte, M }\end{array}$}} & \multirow{4}{*}{$\mathrm{pH}$} & \multicolumn{6}{|c|}{ Electrodes } \\
\hline & & & & \multicolumn{2}{|c|}{$\mathrm{Pt}$} & \multicolumn{2}{|c|}{$\mathbf{N i}$} & \multicolumn{2}{|c|}{$\mathrm{Cu}$} \\
\hline & & & & \multicolumn{6}{|c|}{ Content, atomic $\%$} \\
\hline & $\mathrm{SbOCl}$ & $\mathrm{H}_{2} \mathrm{SeO}_{3}$ & & $\mathrm{Sb}$ & $\mathrm{Se}$ & $\mathrm{Sb}$ & $\mathrm{Se}$ & $\mathrm{Sb}$ & $\mathrm{Se}$ \\
\hline 1 & 0.01 & 0.09 & 1.65 & 28.19 & 71.81 & 21.76 & 78.24 & 0 & 70.73 \\
\hline 2 & 0.025 & 0.075 & 1.73 & 50.29 & 49.71 & 43.05 & 56.95 & 0 & 58.19 \\
\hline 3 & 0.05 & 0.05 & 1.85 & 61.38 & 38.62 & 61.91 & 38.09 & 0 & 47.47 \\
\hline 4 & 0.075 & 0.025 & 1.98 & 82.30 & 17.70 & 75.99 & 24.01 & 0 & 35.31 \\
\hline 5 & 0.09 & 0.01 & 2.1 & 95.34 & 4.66 & 99.47 & 0.53 & 0 & 22.00 \\
\hline
\end{tabular}

*Current density $=2.5 \mathrm{~A} / \mathrm{dm}^{2}$, time of deposition $=60 \mathrm{~min}, T=338 \mathrm{~K}, T_{\text {thermal }}=703 \mathrm{~K}$. 

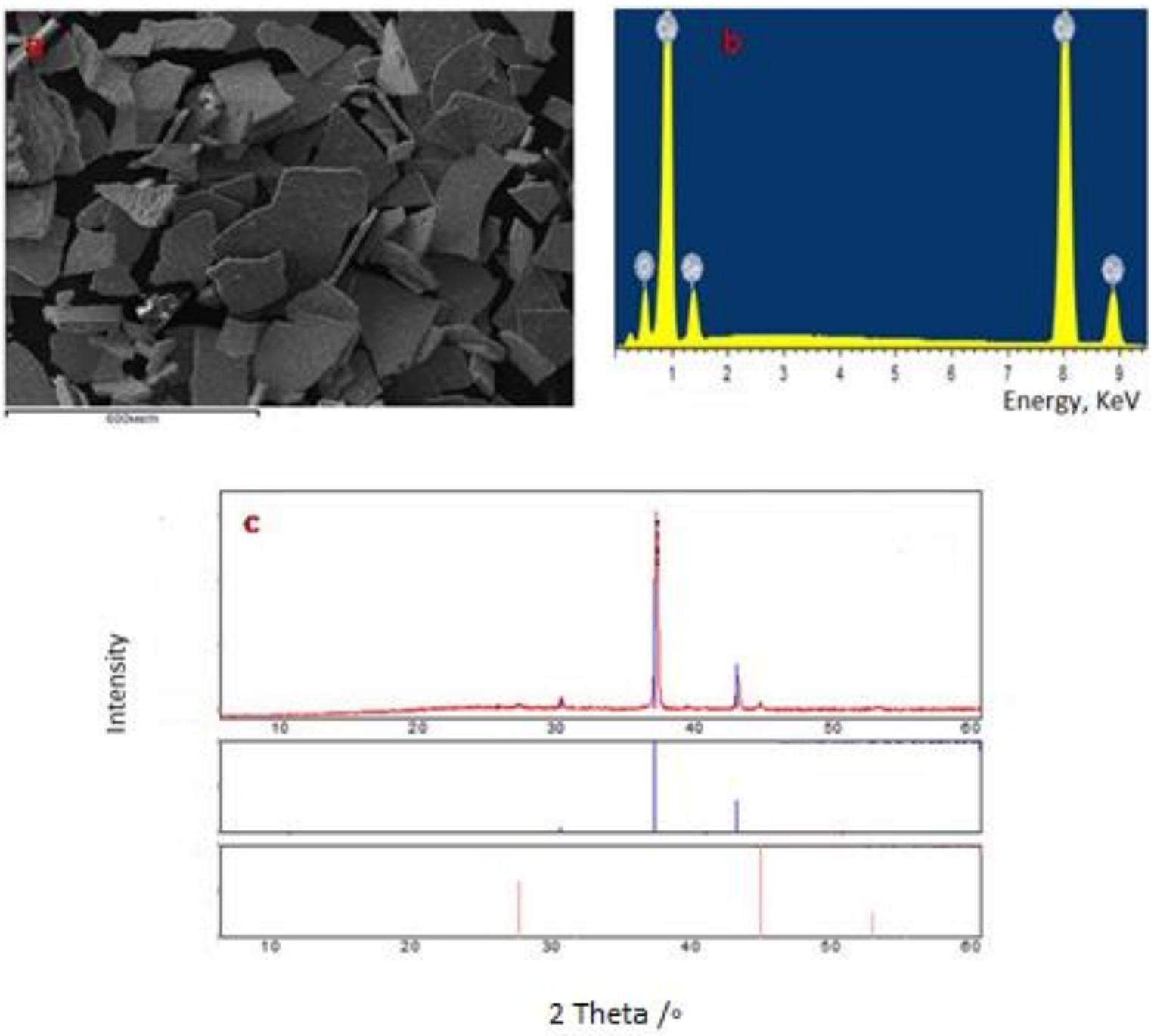

Figure 5. a) SEM, b) EDX and c) X-ray phase analysis of electrodeposited layers on Cu electrode.

The electrolyte composition: $0.05 \mathrm{M} \mathrm{SbOCl}+0.05 \mathrm{M} \mathrm{H}_{2} \mathrm{SeO}_{3}+0.007 \mathrm{M} \mathrm{C}_{4} \mathrm{H}_{6} \mathrm{O}_{6}$, time of electrolysis $=60 \mathrm{~min}$, current density $=2.5 \mathrm{~A} / \mathrm{dm}^{2}, \mathrm{pH} \mathrm{1.85,} \mathrm{T}_{\text {thermal }}=703 \mathrm{~K}$.

\section{Conclusions}

The electrochemical deposition of $\mathrm{Sb}_{2} \mathrm{Se}_{3}$ thin films has been performed by potentiostatic and galvanostatic methods, under various experimental conditions on $\mathrm{Pt}, \mathrm{Cu}, \mathrm{Ni}$ electrodes. The study was conducted by changing the concentration of electrolyte, $\mathrm{pH}$, current density, temperature, etc. The obtained results of CV, X-ray phase and SEM-EDX have shown that thin films of $\mathrm{Sb}_{2} \mathrm{Se}_{3}$ compounds are deposited on Pt and Ni electrodes, but not on Cu electrode. It was found that black, uniform, crystalline and shiny films of the stoichiometric composition of $\mathrm{Sb}_{2} \mathrm{Se}_{3}$ compound are deposited on $\mathrm{Pt}$ and $\mathrm{Ni}$ electrodes at the temperature interval of 338-348 K, pH 1.85, current density of 2.5-3.0 A $/ \mathrm{dm}^{2}$ and $T_{\text {thermal }}=703 \mathrm{~K}$. The optimal electrolyte composition is $0.05 \mathrm{M} \mathrm{SbOCl}+$ $+0.05 \mathrm{M} \mathrm{H}_{2} \mathrm{SeO}_{3}+0.007 \mathrm{M} \mathrm{C}_{4} \mathrm{H}_{6} \mathrm{O}_{6}$.

Acknowledgements: This work was carried out with the financial support of the National Academy of Sciences of Azerbaijan within the framework of research programs in priority areas in 2019-2020.

\section{References}

[1] M. Bouroushian, Electrochemistry of Metal Chalcogenides, Springer-Verlag, Berlin, 2010, p. 358

[2] M. R. Gao, Y. F. Xu, J. Jiang, S.H. Yu, Chemical Society Reviews 42 (2013) 2986-3017. 
[3] A. Qurashi, Metal Chalcogenide Nanostructures for Renewable Energy Applications, A. Qurashi (Ed.), John Wiley -Scrivener Inc. 2014. p. 320

[4] J. Fritsche, A. Klein, W. Jaegermann, Advanced Engineering Materials 10 (2005) 914-920.

[5] A. Shenouda, E. El Sayed, Ain Shams Engineering Journal 6 (2015) 341-346.

[6] A. Eftekhar, Appl. Mater. Today 8 (2017) 1-17.

[7] T. T. Ngo, S. Chavhan, I. Kosta, O. Miguel, H-J. Grande, R. Tena-Zaera, ACS Applied Materials \& Interfaces 6 (2014) $2836-2841$.

[8] R.G. Avilez Garcia, C. A. Meza Avendaño, M. Pal, F. Paraguay Delgado, N. R. Mathews, Materials Science in Semiconductor Processing 44 (2016) 91-100.

[9] J. J. Carey, J. P. Allen, D. O. Scanlon, G. W. Watson, Journal of Solid State Chemistry 213 (2014) 116-125.

[10] J. B. Thorat, S. V. Mohite, A. A. Bagade, T. J. Shinde, V. J. Fulari, K. Y. Rajpure, N. S. Shinde, Materials Science in Semiconductor Processing 79 (2018) 119-126.

[11] Y. Zhou, M. Leng, Z. Xia, J. Zhong, H. Song, X. Liu, B. Yang, J. Zhang, J. Chen, K. Zhou, J. Han, Y. Cheng, J. Tang, Advanced Energy Materials 4 (2014) 13018461-8.

[12] Y. Zhou, L. Wang, S. Chen, S. Qin, X. Liu, J. Chen, D.-J. Xue, M. Luo, Y. Cao, Y. Cheng, E.H. Sargent, J. Tang, Nature Photonics 9 (2015) 409-415.

[13] A. A. Tahir, M. A. Ehsan, U. Wijayantha-Kahagala-Gamage, M. Zeller, A. D. Hunter, Chemistry of Materials 22 (2010) 5084-5092.

[14] D.-E. Lee, J.-Y. Wu, W.-Z. Lin, M.-W. Lee, Journal of Electrochemical Society 14 (2014) H880-H884.

[15] R. Huang, S. L. Benjamin, Ch. Gurnani, Y. Wang, A. L. Hector, W. Levason, G. Reid, C. H. De Groot (Kees), Scientific Reports 6 (2016) 27593-27603.

[16] I. K. El Zawawi, M. A. Mahdy, E. A. El-Sayad, Journal of Nanomaterials (2017) Article ID 7509098.

[17] P. K. Bajpai, S. Yadav, A. Tiwari, H. S. Virk, Solid State Phenomena 222 (2015) 187-233.

[18] G. M. Huseynov, N. A. Mammadova, H. A. Imanov, Chemical Problems 15 (2017) 329-334.

[19] Y. Jiang, X. M. Meng, J. Liu, Z. Y. Xie, C. S. Lee, S. T. Lee, Advanced Materials 15 (2003) 323-327.

[20] P. B. Patil, S. S. Mali, V. V. Kondalkar, R. M. Mane, P. S. Patil, C. K. Hong, P. N. Bhosale, Journal of Electroanalytical Chemistry 758 (2015) 178-190.

[21] A. B. Bhalerao, C. D. Lokhande, B. G. Wagh, IEEE Transactions Nanotechnology 12 (2013) 996-1001.

[22] A. S. Aliyev, M. El-Rouby, International Journal of Thin Film Science and Tecnology 3 (2013) 195-205.

[23] M. El-Rouby, A. S. Aliyev, Advanced Materials Research 787 (2013) 417-422.

[24] A. S. Aliyev, M. Elrouby, S. F. Cafarova, Materials Science in Semiconductor Processing 32 (2015) 3139.

[25] V. Vinayakumar, C. R. Obregón Hernández, S. Shaji, D. A. Avellaneda, J. A. Aguilar Martinez, B. Krishnan, Materials Science in Semiconductor Processing 80 (2018) 9-17.

[26] J. Ma, Y. Wang, Y. Wang, Q. Chen, J. Lian, W. Zheng, Journal of Physical Chemistry C 113 (2009) 1358813592.

[27] S. Messina, M. T. S. Nair, P. K. Nair, Journal of the Electrochemical Society 156 (2009) H327-H332.

[28] A. P. Torane, K. Y. Rajpure, C. H. Bhosale, Materials Chemistry and Physics 61 (1999) 219-222.

[29] A. Tang, M. Long, Z. He, Electrochimica Acta 146 (2014) 346-352.

[30] X. Shi, X. Zhang, Y. Tian, C. Shen, C. Wang, H. J. Gao, Applied Surface Science 258 (2012) 2169-2173.

[31] A. Sh. Aliyev, Sh. O. Eminov, T. Sh. Sultanova, V. A. Mejidzadeh, D. A. Kuliyev, H. D. Jalilova, D. B. Tagiyev, Chemical Problems 14 (2016) 139-145.

[32] V. A. Majidzade, P. H. Guliyev, A. S. Aliyev, M. Elrouby, D. B. Tagiyev, Journal of Molecular Structure 1136 (2017) 7-13.

[33] V. A. Majidzade, A. Sh. Aliyev, P. H. Guliyev, Y. N. Babayev, M. Elrouby, D. B. Tagiyev, Journal of Electrochemical Science and Engineering 8 (2018) 197-204.

[34] V. A. Majidzade, Chemical Problems 16 (2018) 331-336.

[35] A. Sh. Aliyev, V. A. Majidzade, N. Sh. Soltanova, D. B. Tagiyev, V. N. Fateev, Chemical Problems 16 (2018) 178-185.

[36] V. A. Majidzade, S. F. Cafarova, A. Sh. Aliyev, D. B. Tagiyev, Azerbaijan Chemical Journals 3 (2018) 6-10. 
[37] S. F. Cafarova, A.Sh.Aliyev, M. Elrouby, D. B. Tagiyev, Journal of Electrochemical Science and Engineering 5 (2015) 231-235.

[38] Handbook of Electrochemistry, A. M. Sukhotin (Ed.), Leningrad: Khymia, 1981. p. 488 (in Russian).

(C2019 by the authors; licensee IAPC, Zagreb, Croatia. This article is an open-access article distributed under the terms and conditions of the Creative Commons Attribution license (http://creativecommons. org/licenses/by/4.0/) 